\title{
EVALUATION TECHNIQUE OF FRAME RESIDUAL OPERATIONAL LIFE
}

\section{Taras Dovbush; Nadia Khomyk; Anatolii Dovbush; Bogdan Dunets}

\author{
Ternopil Ivan Puluj National Technical University, Ternopil, Ukraine
}

\begin{abstract}
Summary. Step-by-step analytical and experimental investigations of the structural system residual operational life using organic fertilizer spreader PRT-9 are developed in this paper. Increased requirements for metal consumption indicators and reliability of solid fertilizer spreaders are associated with ensuring the strength and durability of their components and units. The agricultural machine frame is the welded metal structure, made mainly of thin-walled elements of open and closed intersections, operating mainly for bending and torsion. The most common defects of such intersections are fatigue edge cracks.
\end{abstract}

Key words: machine operational life, tension, crack, dangerous intersection, correction function.

Statement of the problem. Increased requirements for metal strength and reliability of agricultural machinery structural systems is related to ensuring the strength and durability of components and units. The need to reduce the design time of new equipment, high costs of experimental research increase the value of calculation and experimental of structure durability evaluation. Therefore, the development and substantiation of such methods is the complex task requiring the in-depth analysis of the theory problems for machine bearing systems strength calculations, explanation of new calculation models for crack development and bearing systems load.

Analysis of the available investigations. The results of theoretical and experimental investigations of the residual operational life calculation for frame structures made of open and closed intersections are given in papers $[6,7]$. These investigations are insufficient to determine the operational life of the constructive fertilizer spreader system PTR-9.

The objective of the paper is to develop step-by-step method for evaluating the residual operational life of machine bearing system for solid organic fertilization.

Statement of the problem. The problem is to carry out the analytical investigation of the stress-strain state (SSS) of the constructive system of solid fertilizer spreader with the maximum load randomly distributed along the body space; to check the results experimentally; to investigate the SSS risk of the bearing system dangerous section in field environment, and to determine the average operating stresses during the process. Experimentally determine the characteristics of the cyclic fracture strength of the material from which the profiles of the structural system are fabricated as well as to determine the residual operational life of Z-shaped transverse profile in dangerous section.

The results of the investigation. The resource of the operation of structural system elements of the fertilizer spreader is determined by formula [5]: 


$$
T_{i}=\frac{\int_{l_{0}}^{l_{K_{i}}} \frac{d L}{C\left(\sigma_{i} \sqrt{\pi \cdot L} \cdot F_{Z_{i}}(\varepsilon)\right)^{n}}}{3600 \cdot \omega}
$$

where $\sigma_{i}$ - actual stresses in the investigated elements of metal structure;

$F_{Z_{i}}-$ generalizing correction function for $i$-th cross-section of the investigated structural element;

$l_{K_{i}}$ - critical defect value defined by calculation - analytical method.

The determination of the actual stresses in metal structure elements is divided into two stages. At the first stage, we carry out analytical investigations of the stress-strain state (SSS) of structural system under maximum load. Let us show it on the example of the frame calculation for the of organic fertilizer spreader PTR-9.

The distribution of organic fertilizers weight on the spreader body space has mainly variable form both in transverse and longitudinal planes. To describe functionally the nature of distributed load influence on the load-bearing capacity of the spreader elements is an important task for design-and-engineering practice.

Let us consider and systematize the disturbing factors of uneven loading on PTR-9 spreader body space (Fig. 1).

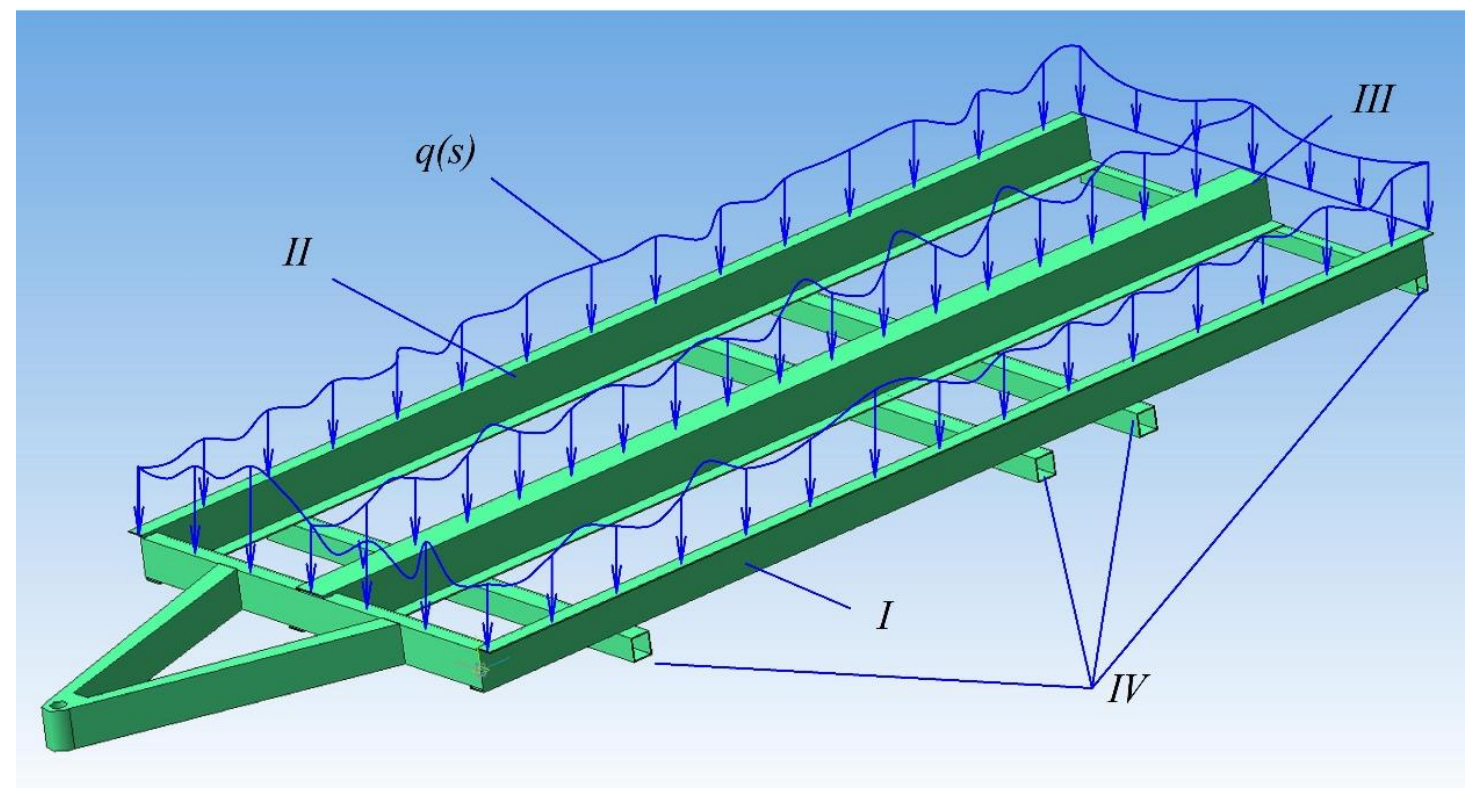

Figure 1. Cycle counting of load distribution of load-bearing metal structure of fertilizer spreader PRT-9: $q(s)$ is distributed load;

I, II are lateral spars of Z-shaped cross-section;

III is central spar with cross section made of two Z-shaped profiles; IV are cross-beams of tubular cross-sections

The calculation of static structural system uncertainty of fertilizer spreader is carried out according to the calculation scheme while applying the modified method of minimum potential deformation energy $[3,4]$.

The distributed external loads $q_{11}(s), q_{12}(s), q_{21}(s), q_{22}(s), q_{31}(s)$, acting on the frame are shown in the calculation scheme Fig. 2. 


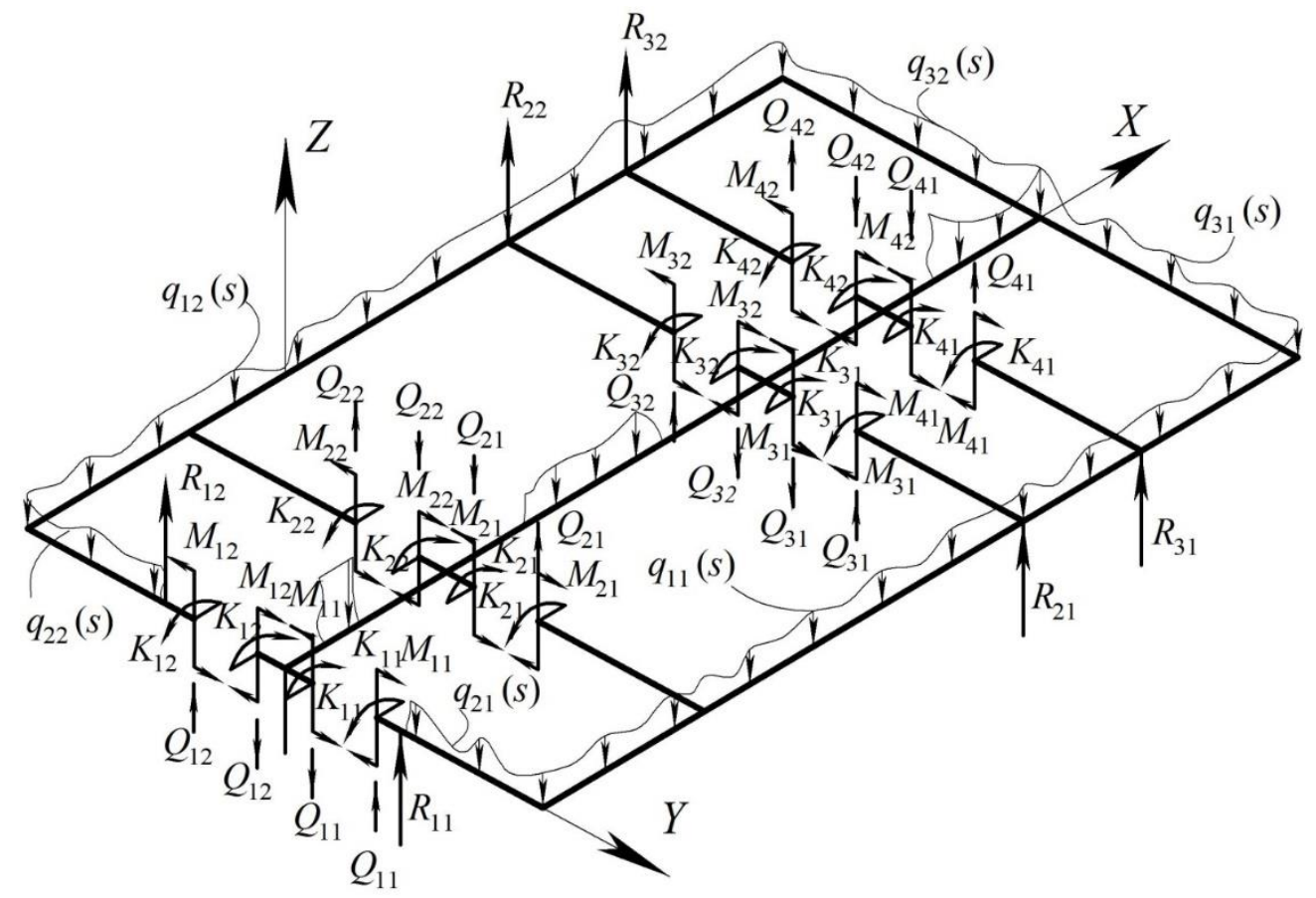

Figure 2. Cycle counting of the structure system loading of fertilizer spreader PRT-9

Such internal force factors occur in the frame cross-sections:

$Q_{11}, Q_{12}, \ldots, Q_{42}$ - transverse forces in the structural system elements;

$M_{11}, M_{12}, \ldots, M_{42}$ - bending moments in the structural system elements;

$K_{11}, K_{12}, \ldots, K_{42}$ - torque in the structural system elements

We reveal the static uncertainty and construct the bending moments diagram for symmetric placement of organic fertilizers (Fig. 3) [5].


Figure 3. Diagram character of the load on the frame and bending moments diagram of the spreader PRT-9 
At the second stage, we carry out experimental investigations focused on the determination of stresses required to verify the analytical calculations reliability. These investigations do not take into account the efforts caused by random disturbance sources: machine movement by the field irregularities, the unevenness of the operating elements movement associated with the implementation of technological process (fertilizer spreading). To determine the real SSS of the fertilizer spreading system, it is necessary to determine additional dynamic loads from the fertilizer weight on the trailer. They occur as the result of vertical accelerations.

The following flow chart was used: loading of organic fertilizers from the pile; motion along the field with nominal load; motion along field with fertilizer spreading; motion along the field with empty body during the experimental investigations.

The strain gauges were installed in zones of the greatest predicted stresses determined during the preliminary analytical static load investigation of the bearing metal structure, as well as the result of statistical data processing concerning the investigated elements failure during operation. The sensors were glued on sections along the stress action direction line. Taking into account the symmetry of the spreader PRT-9 frame relatively to the longitudinal axis, the strain gauges were placed on the right side of the machine [5].

According to the results of analytical investigations of the fertilizer spreader PRT-9 frame [5] the sections, where maximum internal force factors, and respectively, the stress were defined, because of the gauges installed in these sections. The proposed schematic diagram of gauges location on the spreader PRT-9 carrier frame is shown in Fig. 4

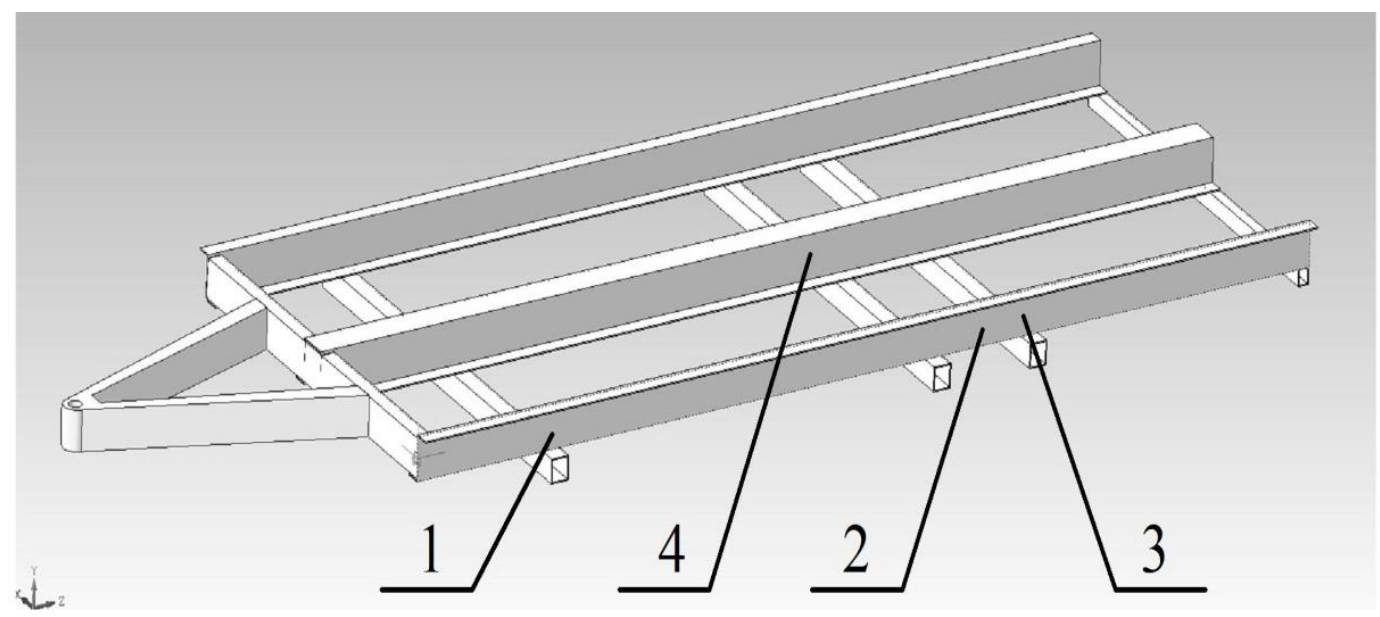

Figure 4. Schematic diagram of strain gauges and acceleration sensor location on the fertilizer RTR-9 spreader frame

The experimental SSS definitions of the trailer spreader for organic fertilizers FRT-9 was carried out under operating conditions during the flow chart: loading of organic fertilizers from the pile, aggregate motion along the field road and directly along the field during fertilizer transportation and spreading, as well as returning to the pile in idle mode (Fig. 5).

For the reliability of indicators obtained during the experiment, we compare the strain gauge readings with analytical results in static mode. In this case, the strain gauge readings take into account the stressed state caused by technological load. Stress components from the metal structure weight and technological cargo are obtained as accumulative values.

The results of experimental frame SSS investigations proved that the calculation and experimental data under static load differ up to $7 \%$ [5]. 


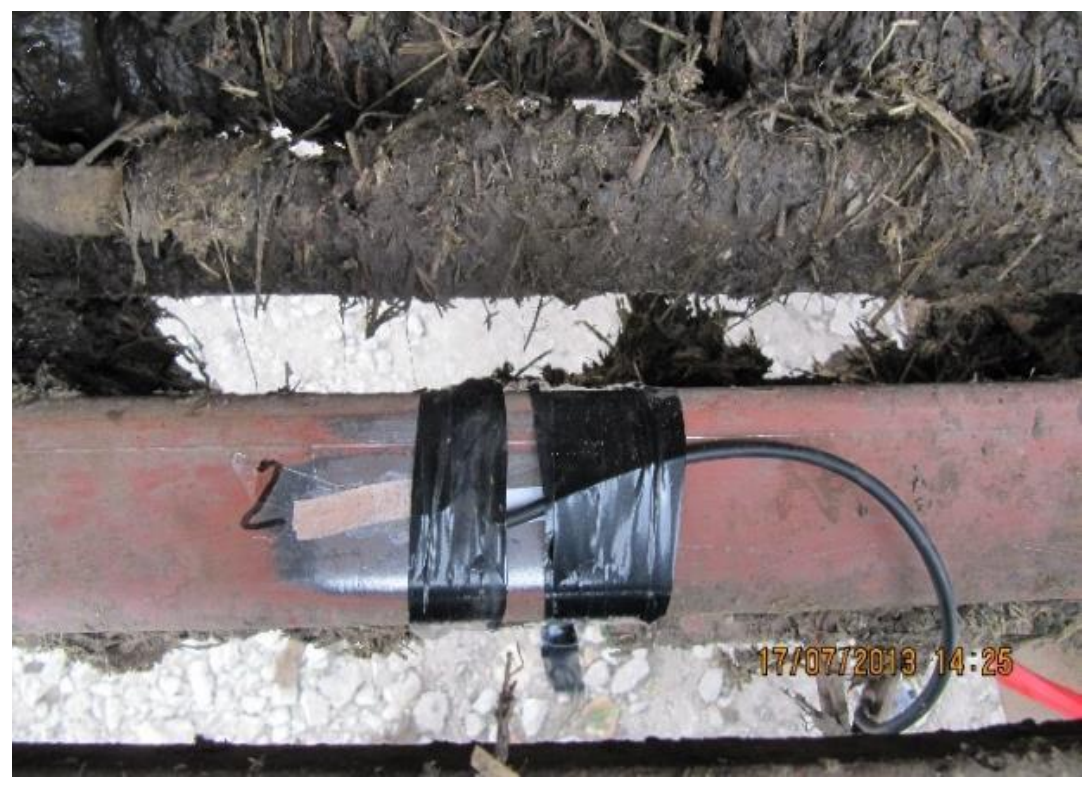

Figure 5. TRT-9 transporting test mode and strain gauge location

The results of experimental investigation during the flow chart performance show the load changes of different frequency and amplitude indicating complex multifrequency random phenomena (Fig. 6). Harmonics of the main frequency tone is $1 \ldots 3,5 \mathrm{~Hz}$.

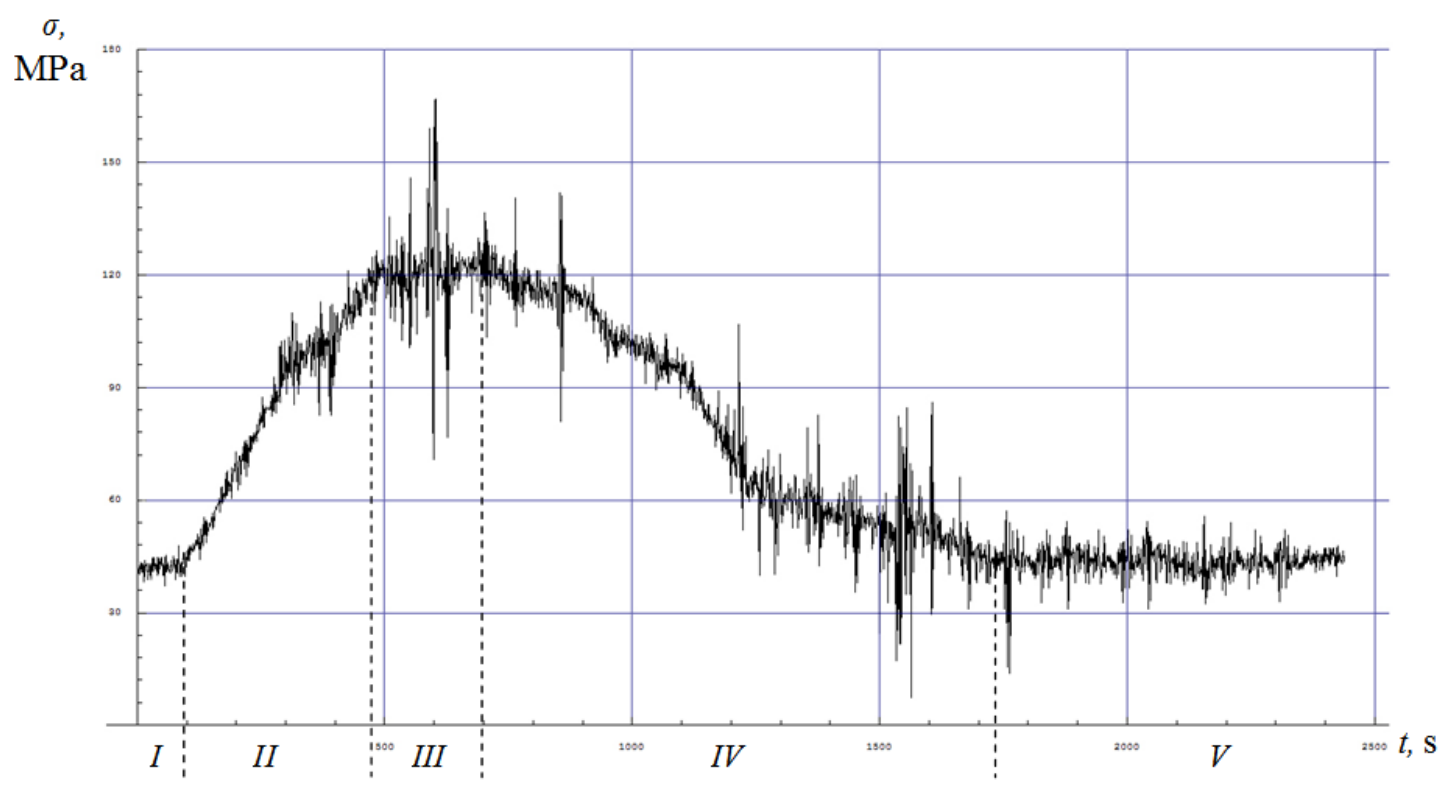

Figure 6. Oscillogram of stress change in the organic fertilizers spreader element in crossing \# 2 : $I$ is the spreader motion without organic fetilizers $\left(t_{1} \approx 13 \mathrm{~min}, \sigma_{1 c p}=20 \mathrm{MPa}\right) ; I I$ is loading of organic fertilizers load $\left(t_{2} \approx 6,5 \mathrm{~min}, \sigma_{2 c p}=75 \mathrm{MPa}\right) ; I I I$ is the spreader motion to the field ( $\left.t_{3} \approx 3,5 \mathrm{~min}, \sigma_{3 c p}=118 \mathrm{MPa}\right) ; I V$ is organic fertilizer spreading $\left(t_{4} \approx 19 \mathrm{~min}, \sigma_{1 c p}=85 \mathrm{MPa}\right)$

Let us determine the average normal operating stress for section \#2 of the structural system of organic fertilizer spreader PRT-9 by the formula 


$$
\sigma_{c p . e}=\frac{\sigma_{1 c p} \cdot t_{1}+\sigma_{2 c p} \cdot t_{2}+\sigma_{3 c p} \cdot t_{3}+\sigma_{4 c p} \cdot t_{4}}{t_{1}+t_{2}+t_{3}+t_{4}} .
$$

In numerical form

$$
\sigma_{c p . e}=\frac{20 \cdot 13+75 \cdot 6,5+118 \cdot 3,5+85 \cdot 19}{13+6,5+3,5+19}=66 \mathrm{MPa} .
$$

As the result of analytical investigations [5], the generalized correction function for Zshaped cross-section is obtained:

$$
\begin{aligned}
& F_{Z}=1-2,586 \cdot \varepsilon+132,249 \cdot \varepsilon^{2}-1628,850 \cdot \varepsilon^{3}+5035,670 \cdot \varepsilon^{4}+ \\
&+54598,249 \cdot \varepsilon^{5}-579311,0 \cdot \varepsilon^{6}+2,457 \cdot 10^{6} \cdot \varepsilon^{7}-5,753 \cdot 10^{6} \cdot \varepsilon^{8}+ \\
&+7,786 \cdot 10^{6} \cdot \varepsilon^{9}-5,724 \cdot 10^{6} \cdot \varepsilon^{10}+1,775 \cdot 10^{6} \cdot \varepsilon^{11}
\end{aligned}
$$

For Z-shaped thin-walled profile with dimensions $200 \times 87 \times 6 \mathrm{~mm}$, the corrective functions in graphical format are shown in Fig. 7
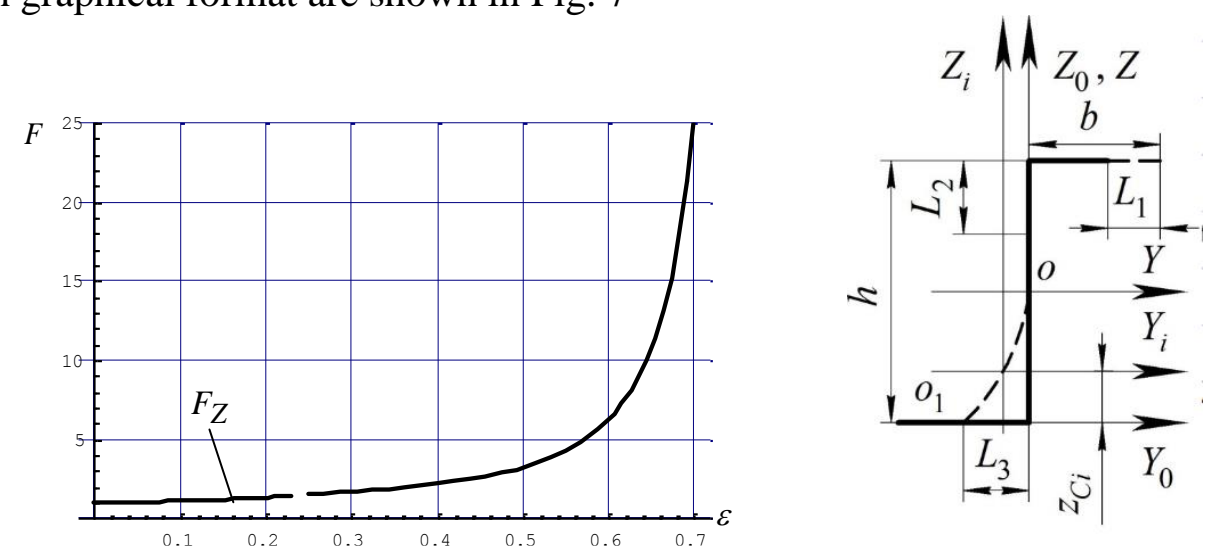

Figure 7. Dependence of the function $F_{Z}$ on the defect value for $\mathrm{Z}$-shaped thin-walled section with dimensions $200 \times 87 \times 6 \mathrm{~mm}$

According to the processing of experimental investigation results, we obtained the characteristics of cyclic fracture toughness of the material (Steel 10), the sections of fertilizer spreader structural system were made of: $K_{f c}=71,5 \mathrm{MPa} \sqrt{\mathrm{m}} ; \quad C=8,75 \cdot 10^{-12} \mathrm{~m} /$ cycle $\cdot(\operatorname{MPa} \sqrt{\mathrm{m}})^{n} ; n=2,94$, where $K_{f c}$ - the critical SIV value at which the sample failure occurs; $n$ - the inclination angle tangent of the kinetic diagram rectilinear part for fatigue failure of the frame material to the abscissa;

$C$ - characteristics of the material due to which the material specific properties at the crack top in the weld seam area.

Side spares of the spreader PRT-9 bearing system are made of Z-shaped cross-sections with dimensions 200x86x6 mm. For the average operational stresses $66 \mathrm{MPa}$, the diagram of SIV dependence on the crack development (Fig. 8) was built and the crack length at which the material failure occurs is determined, $l_{K_{1}}=0,1135 \mathrm{~m}$. 



Figure 8. Graphical interpretation of the boundary crack development in Z-shaped cross-section of PRT-9 frame side spare

Having solved equation (1) at $n=2,94 ; \quad C=8,75 \cdot 10^{-12} \mathrm{~m} / \mathrm{cycle} \cdot(\mathrm{MPa} \sqrt{\mathrm{m}})^{n}$; $\omega=2,3 \mathrm{~Hz}$; we get the residual operation life of PRT-9 frame side spar in dangerous section (Fig. 9).

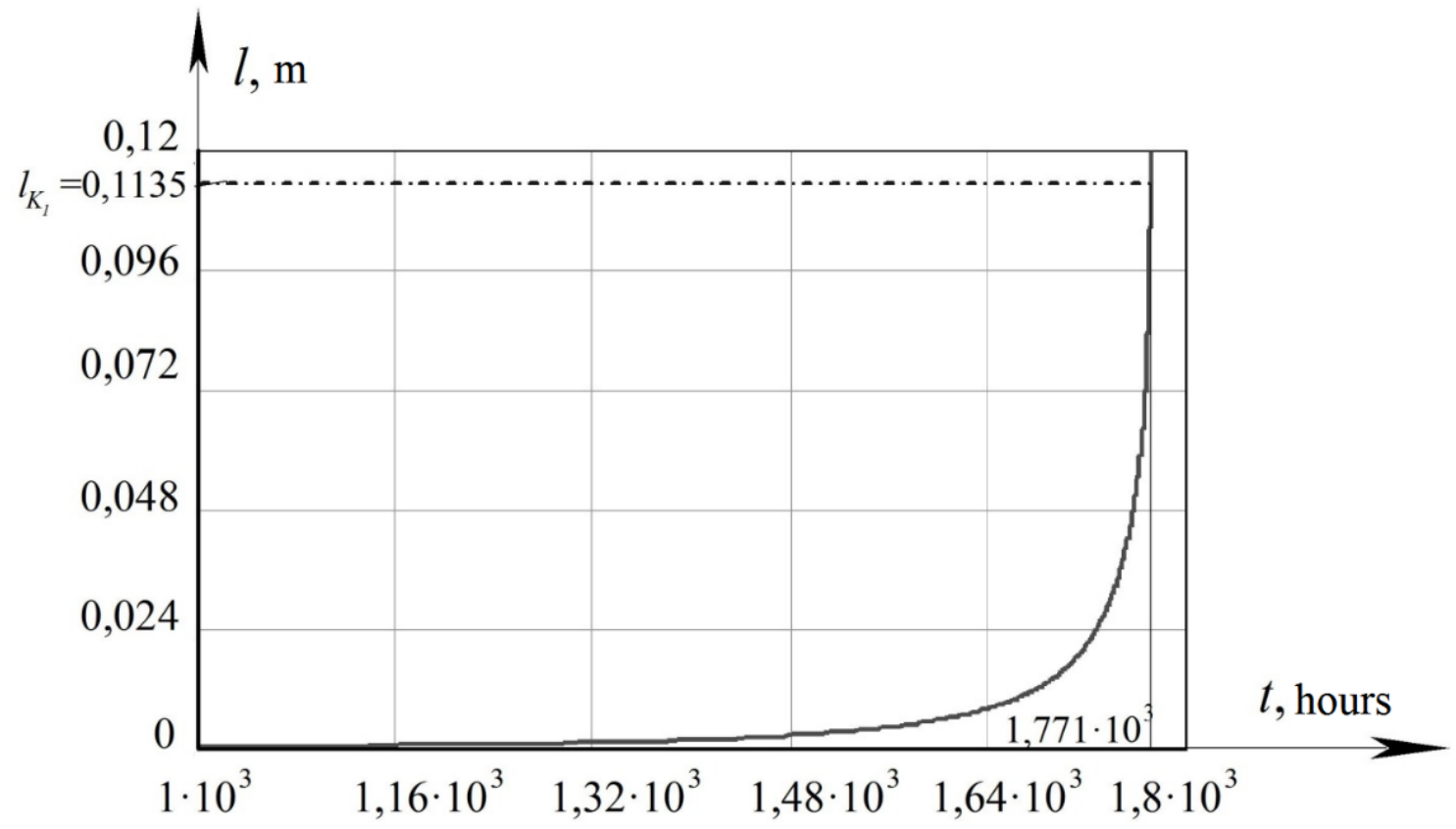

Figure 9. Residual operational life of the side spar of PRT-9 frame 
Thus, the calculating operational life of the side span of PRT-9 frame the frame is $T_{1}=1771$ hours.

Conclusion. Analysis of analytical and experimental investigations of the bearing system of solid organic fertilizers PRT-9 spreader at its complete loading indicates the disadvantages of the frame structure, i. e., unsatisfactory stressed state. Due to the experimental investigations of fracture toughness it is determined that in terms of brittle fracture, zones of the weld seam thermal impact are dangerous. As the result of Steel 10 material investigations, the following characteristics of fracture toughness $K_{f c}=71,5 \mathrm{MPa} \sqrt{\mathrm{m}} ; \quad C=8,75 \cdot 10^{-12} \mathrm{~m} / \mathrm{cycle}$ $(\mathrm{MPa} \sqrt{\mathrm{m}})^{n} ; n=2,94$ were determined.

\section{References}

1. Rybak T. I., Dovbush T. A. Modification of MMPED for the disclosure of static uncertainty of curvilinear elements of frames, Ternopil, All-Ukrainian Student Scientific and Technical Conference "Natural and Humanitarian Sciences: Actual Issues". Collection of abstracts of the conference. Volume 1. 2013. 143-143 pp.

2. Rybak T. I. Search engineerings based on the optimization of the resource of mobile agricultural machines. Ternopil, 2003. 332 pp.

3. Rybak T. I., Pidhurskyi M. I., Kostiuk V. I. Universal measuring system for studying the dynamics of agricultural machines, Reliability and durability of machines and structures, issue 25, 2005, 112-119 pp.

4. Rybak T. I. The study of the carrying capacity of spatial frame structures of some agricultural machines the author's abstract of the candidate's dissertation. Lviv, 1972. $18 \mathrm{p}$.

5. Dovbush T. A. Estimation of the resource of work and substantiation of the design of the carrier system of fertilizer spreaders: a thesis for obtaining sciences. degree of Candidate Degree specialty 05.05.11/ Ternopil: TNTU. Ternopil, 2016. 189 pp.

6. Rybak T. I, Stashkiv M. Y. Determination of CIN for fatigue crack in a thin-walled core of a closed profile at the deplanation of its transverse sections. Machine Science. 2003. 10-13 pp.

7. Rybak T. I, Stashkiv M, Y. Specificity of calculation of some thin-walled elements of trimming constructions of machines. Bulletin of the TSTU volume 8, № 2. Ternopil, 2003. 34-49 pp.

\section{Список використаної літератури}

1. Рибак Т. І., Довбуш Т. А. Модифікація ММПЕД для розкриття статичної невизначеності криволінійних елементів рам: VI Всеукраїнська студентська науково-технічна конференція «Природничі та гуманітарні науки. Актуальні питання». Збірник тез конференції. Том 1. Тернопіль: THTУ, 2013. C. 143.

2. Рибак Т. І. Пошукове конструювання на базі оптимізації ресурсу мобільних сільськогосподарських машин. Тернопіль: Збруч, 2003. $332 \mathrm{c.}$

3. Рибак Т. І., Підгурський М. І., Костюк В. І. та ін. Універсальна вимірювальна система для дослідження динаміки сільськогосподарських машин. Надійність і довговічність машин і споруд. 2005. Вип. 25. С. 112-119.

4. Рыбак Т. И. Иследование несущей способности пространственных рамных конструкций некоторых сельськохозяйственных машин: автореф. дис. ... канд. техн. наук. Львов, 1972. 18 с.

5. Довбуш Т. А. Оцінка ресурсу роботи і обгрунтування конструкції несучої системи розкидачів добрив: дис. ... канд. техн. наук.: спеціальність 05.05.11 / ТНТУ. Тернопіль, 2016. 189 с.

6. Рибак Т., Сташків М. Визначення КІН для втомної тріщини у тонкостінному стержні замкнутого профілю при депланації його поперечних перетинів. Машинознавство. 2003. № 5. С. 10-13.

7. Рибак Т., Сташків М. Специфіка розрахунку деяких тонкостінних елементів тримких конструкцій машин. Вісник ТДТУ. 2003. Т. 8. № 2. С. 34-39. 


\title{
УДК 539.3
}

\section{МЕТОДИКА ОЦНЮВАННЯ ЗАЛИШКОВОГО РЕСУРСУ РОБОТИ РАМНИХ СИСТЕМ}

\section{Тарас Довбуш; Надія Хомик; Анатолій Довбуш; Богдан Дунець}

\author{
Тернопільський національний технічний університет імені Івана Пулюя, \\ Тернопіль, Україна
}

\begin{abstract}
Резюме. Розроблено покрокові аналітико-експериментальні дослідження оцінювання залишкового ресурсу роботи конструктивної системи на прикладі розкидача органічних добрив ПРТ-9. Підвищення вимог до показників металоємності й надійності розкидачів твердих добрив пов'язане $з$ забезпеченням міцності й довговічності їхніх вузлів та агрегатів. Необхідність скорочення термінів проектування нової техніки, високі витрати на проведення експериментальних досліджень підвищують вагомість розрахунково-експериментальних методів оцінювання довговічності конструкцій. Надійність і довговічність мобільних сільськогосподарських машин масового виробниитва визначається, в основному, міцністю їх тримких рам. Сприймаючи динамічні навантаження від ходової частини машини, а також від змонтованих на ній силових і функиіональних установок, иі конструкиії працюють у жорстких умовах цииклічного навантаження, щчо часто призводить до їх передчасного руйнування. Відмови тримких вузлів мобільних сільськогосподарських машин, викликані зародженням та ростом втомних тріщин. Тому при проектуванні та розрахунку иุих конструкиій доиільно оцінювати їх тріщиностійкість використовуючи підходи механіки руйнування. Такі дослідження не є заміною традиційних методів розрахунку, а $\epsilon$ важливим додатковим заходом, що дозволяє коректніше оцінити очікуваний запас міцності й ресурсні можливості конструкиії, вибрати матеріал і оптимальні конструктивні рішення окремих деталей та вузлів з точки зору їх тріщиностійкості, розробити практичні рекомендації для попередження втомних руйнувань і збільшення терміну експлуатації машин [2, 4]. Рама сільськогосподарської машини-ие зварна металоконструкція, виготовлена, в основному, з тонкостінних елементів відкритих $i$ закритих перетинів, які працюють переважно на згин та кручення. Найпоширенішими дефектами таких перетинів є втомні крайові тріщини.
\end{abstract}

Ключові слова: ресурс роботи машини, напруження, тріщина, небезпечний перетин, поправочна функиія.

https://doi.org/10.33108/visnyk_tntu2019.01.061

Отримано 22.03.2019 